\section{Hoje, o futebol de mulheres}

Today, Women's Football

É muito comum em nosso cotidiano referirmos ao Brasil como país do futebol. No entanto, uma parte dessa história ficou esquecida, pois por quase quatro décadas, as mulheres foram oficialmente proibidas de jogar bola (1941-1979) - a regulamentação do futebol feminino aconteceu apenas no ano de 1983. Tal interdição retardou o desenvolvimento da modalidade cujas consequências ainda hoje se fazem notar tais como a falta de profissionalização, visibilidade e reconhecimento.

Com o intuito de promover e aprofundar as discussões em torno do futebol feminino, tanto no Brasil como na América Latina, a presente edição da revista FuLiA / UFMG apresenta o dossiê FUTEBol E MULHERES, que ana- lisa a presença das mulheres no futebol em suas diversas manifestações e ocupações, evidenciando que apesar das dificuldades encontradas, as mulheres sempre se fizeram presentes nesse esporte e por meio dele exerceram (e exercem) atividades profissionais, de lazer, de educação e sociabilidade.

Para tanto, na seção Dossiê, apresentamos o artigo "Apresentadora, torcedora ou jogadora: Fernanda Gentil, Larissa Riquelme e Marta nas representações das mulheres pelo jornalismo esportivo", de Thalita Neves, que propõe uma discussão sobre as questões de gênero no jornalismo esportivo, um campo dotado de raízes que também envolvem preconceitos de raça e orientação sexual, ao mesmo tempo em que se configura como uma área em potencial para a contextualização da sensibilidade e subjetividade jornalísticas.

Por sua vez, Carolina Bortoleto Firmino, com o artigo "Empoderamento e relações de poder: a cobertura femi- 
nista da Copa do Mundo da Rússia pelo projeto dibradoras", analisa como o blog dibradoras acompanhou a Copa do Mundo de Futebol Masculino, na Rússia, em 2018, apoiado na compreensão do empoderamento como o processo de questionar ideologias e relações de poder.

Já, o ensaio de Brenda Elsey, traduzido ao português por Larissa Brainer, "Energizadas pelo movimento de mulheres \#NiUnaMenos, as equipes de futebol feminino desafiam os patriarcas do esporte-rei da América Latina", contribui para o presente dossiê com algumas questões emergentes que gravitam em torno do futebol feminino na América Latina, como a falta de reconhecimento das próprias instituições que dirigem o futebol.

Por meio do artigo "Estética do movimento e adestramento do olhar: considerações sobre o futebol brasileiro de mulheres", de natureza teórico-conceitual, a autora Talita Machado Vieira questiona os juízos de torcedores sobre o futebol de rendimento praticado por mulhe- res, qualificando-o como pouco estimulante e não atrativo. E afirma que o futebol praticado por mulheres não evoca, por si mesmo, uma experiência estética desagradável, mas convoca a ampliação das sensibilidades do torcedor para acolher outras formas de manifestação desse esporte.

Outra contribuição é o ensaio de Caroline Soares de Almeida, "O Estatuto da FIFA e a igualdade de gênero no futebol: histórias e contextos do Futebol Feminino no Brasil", que analisa as mudanças ocorridas no futebol feminino brasileiro a partir da introdução da igualdade de gênero no estatuto da FIFA, em 2016, e apresenta uma reflexão sobre os relatos observados durante o trabalho de campo no interior do estado de São Paulo e as notícias publicadas em diferentes veículos de comunicação sobre essa temática.

"Precisamos falar sobre futebol, precisamos falar sobre a mulher nesse espaço esportivo", de Naiara Souza da 
Silva, traz reflexões oriundas de sua tese Futebol e ideologia: a língua e a tatuagem no discurso de sujeitos torcedores da dupla Bra-Pel, escrita a partir dos pressupostos teóricos da Análise do Discurso (AD) de tradição em Michel Pêcheux. Especificamente, traz um recorte que diz respeito às mulheres torcedoras do Pelotas quando materializam em seus corpos tatuagens representativas do seu time de preferência.

Por fim, o dossiê conta com o artigo "Un análisis de las representaciones mediáticas y las desigualdades estructurales en el fútbol de mujeres en Argentina", de Verónica Moreira e Martín Álvarez Litke, que estuda a relação conflituosa entre atletas, instituições esportivas e a mídia, destacando a desigualdade e o tratamento discriminatório em relação aos futebolistas do sexo feminino nessas áreas. Para tanto, por um lado, a autora diagnostica as representações dos futebolistas no jornal Olé, e, por outro lado, analisa os dados da observação feita durante o trabalho de campo no Club Atlético Boca Juniors.

Na seção Entrevista, "Sissi, a Imperatriz: entrevista com Sisleide Lima do Amor", Silvana Vilodre Goellner conversa com a jogadora Sissi, em Concord, Estados Unidos, e aborda aspectos de sua trajetória esportiva, jogadora fundamental da primeira geração de futebolistas depois de revogado o Decreto-Lei 3.199.

A seção Resenha apresenta "La Nuestra Fútbol Feminista: experiencias de un juego posible", projeto argentino que visa o alargamento da prática futebolística de mulheres, desenvolvido por Maria Jose Berardi, Corina Russo, Jimena Aon, Victoria Dominich, Emiliano Royano, Juliana Lozano e Monica Santino. Ainda nessa seção, seguem os textos sobre os livros Sabe aquele gol que o Pelé não fez? Eu fiz!: a trajetória esportiva de Duda (2018), de Silvana Vilodre Goellner e Suellen dos Santos Ramos, apresentado por Thiago Carlos Costa, e Entre as quatro linhas: con- 
tos sobre futebol (2013), organizado por Luiz Ruffato, escrito por Gustavo Cerqueira Guimarães.

A seção Poética, dedicada às múltiplas possibilidades das abordagens artísticas do futebol e do mundo dos esportes, traz a bela canção "Alexia”, de Samuel Rosa e Nando Reis, presente no álbum Velocia (2014), do Skank. Por fim, a revista mostra nove fotografias de mulheres praticando o futebol, de Daniel Kfouri, que fizeram parte da exposição "Futebol e mulheres no país da Copa", realizada na Usina do Gasômetro, em Porto Alegre, ao longo da Copa do Mundo FIFA 2014.

Desejamos uma boa leitura!

Porto Alegre e Lajinha/MG, 12 de junho de 2019.

Silvana Vilodre Goellner Escola de Educação Física, Fisioterapia e Dança - UFRGS

Gustavo Cerqueira Guimarães FULIA / Faculdade de Letras - UFMG

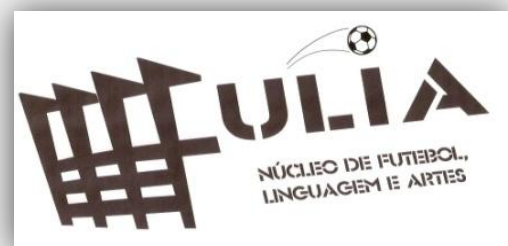

